\title{
Antioxidant activity and analgesic assessment of Lansium domesticum stem bark infusion
}

\author{
PRATIWI APRIDAMAYANTI, INARAH FAJRIATY, ETNI HATITA \\ Department of Pharmacy, Faculty of Medicine, Universitas Tanjungpura. Jl. Prof. Hadari Nawawi, Pontianak 78121, West Kalimantan, Indonesia. \\ Tel.: +62-561-765342, 583865, 732500, Fax.: +62-561-765342, `email: apridamayanti.pratiwi@gmail.com
}

Manuscript received: 12 December 2017. Revision accepted: 22 March 2018.

\begin{abstract}
Apridamayanti P, Fajriaty I, Etni Hatita E. 2018. Antioxidant activity and analgesic assessment of Lansium domesticum stem bark infusion. Nusantara Bioscience 10: 71-75. Langsat (Lansium domesticum Correa) is empirically used as a medicine for fever and pain. This study intended to determine the effectiveness of stem bark infusion of langsat as an antioxidant and analgesic. Antioxidant activity test was performed by DPPH method (2,2 Diphenyl-1-picrilhydrazil), with infusion at concentration of 1000, 2000, 3000, 4000 and $5000 \mathrm{ppm}$. Absorbance of the sample was measured using a UV-Vis spectrophotometer. The analgesic test was performed on male Swiss mice by Writhing test using acetic acid $0.6 \%$, CMC-Na induced negative control, Paracetamol $65 \mathrm{mg} / \mathrm{kg}$ BW induced positive control, dose I (65 mg/kg BW), dose II (130 mg/kg BW) and dose III (195 mg/kg BW). Data was analyzed using One Way ANOVA in SPSS and the percentage of writhing protection at each dose was calculated. The results of phytochemical metabolites screening of stem bark infusion showed the presence of flavonoids, terpenoids/steroids, tannins, phenols and saponins. Antioxidant activity measured by spectrophotometric measurements showed that the antioxidant activity of stem bark infusion was $\mathrm{IC}_{50} 2820 \mu \mathrm{g} / \mathrm{ml}$. The percentage of writhing protection on dose I, II, and III was $57.52 \%, 42.48 \%$ and $24.51 \%$ respectively, showing a significant difference with negative control at minute 5, 10 and $15(\mathrm{P}<0,05)$. There were no significant differences between positive control and dose I, at minute 30 to minute $60(\mathrm{P}>0,05)$. The effective dose of stem bark infusion was obtained as an analgesic at dose of $65 \mathrm{mg} / \mathrm{kg} \mathrm{BW}$ from 30 to 60 minutes.
\end{abstract}

Keywords: Analgesic, antioxidant, Lansium domesticum

\section{INTRODUCTION}

Langsat plant, especially its stem bark is empirically used by dayaknese ethnic society in West Kalimantan Province as an antipyretic and analgesic medication. Based on Medicinal Plants and Herb Research in 2015, dayaknese society in Sekajang hamlet, West Kalimantan, used langsat stem bark as infused water. The residue of the stewing process is grounded and applied to an injured body part (Sadeli et al. 2015).

The dried langsat stem bark in the form of ethanolic extract contains secondary metabolites i.e alkaloids, flavonoids, saponins, tannin, and triterpenoids (Semuel 2008). According to Subandrate et al. (2016), the extract of duku seed with dose of $100 \mathrm{mg} / \mathrm{kg}$ BW has an optimum potency as an antioxidant. Duku seed extract was able to increase GSH (glutathione) and lowers MDA (malondialdehyde) in alcohol-induced rats. GSH is a tripeptide having sulfhydryl/thiol (-SH) groups that can counteract free radicals while MDA is the final product of lipid peroxidation by free radicals (Subandrate et al. 2016). Based on research by Mokosuli (2008), the ethanolic extract of raw langsat stem bark and its dried counterparts with a concentration of $250 \mathrm{ppm}$ possessed the yield inhibition value of $57.72 \%$ and $55.78 \%$ respectively. This result was better than the inhibition percentage of BHT as the control group $(43.38 \%)$ at the same concentration. Butylated hydroxytoluene (BHT) is a lipophilic organic compound (fat soluble), chemically a derivative of phenol, which is a synthetic antioxidant.
Free radical is a molecule, atom or groups of atom with one or more unpaired electron in its outermost orbital (Muchtadi 2013). Free radicals were suspected to be the cause of some diseases including cardiovascular disease, cancer, and aging. More than $60 \%$ of new cases and about $70 \%$ of death caused by cancer occurred in around the world especially in Africa, Asia, Central and South America (Ministry of Health of the Republic of Indonesia 2015). Adverse effects caused by free radical towards body could be prevented using substances called antioxidants. Antioxidant is a chemical substance, which can donate one or more electron to free radical, thus suppressing it (Kurniawan 2011).

A metabolite compound containing antioxidant properties is being able to inhibit the activity of cyclooxygenase enzyme. Cyclooxygenase is an enzyme, which is responsible for the synthesis of pain mediator, namely prostaglandin. Pain is defined as sensory and emotional feeling of uncomfortable, which is tied to (the threat of) tissue damage (Tjay and Rahardja 2007). In England, it is reported that 17.3 million British people have at least experienced back pain in time, and 1.1 million of them were disabled due to back pain. In Indonesia, the prevalence was $7.6 \%$ to $37 \%$. (Koesyanto 2013). The compound, which contains polyphenol and flavonoid, is reported to be able to inhibit cyclooxygenase enzyme and has been proven to have the activity for capturing free radicals (Ebadi 2001). The use of antioxidant-based from nature is mainly developed because of its minimum side effects. Therefore, the objective of this research was to 
determine the antioxidant potency of Langsat (Lansium domesticum Correa) as one of the native Indonesian plants.

\section{MATERIALS AND METHODS}

\section{Extraction}

The sample used in this research was the stem bark of langsat (Lansium domesticum Correa), which were obtained in the forest area of Sekajang hamlet, Suruh Tembawang village, Entikong district, Sanggau Regency, West Kalimantan. 25 grams of langsat stem bark powder was poured into an infusion pot, and $250 \mathrm{ml}$ of aquadest were added. The mixture was heated for 15 minutes, which was started at the temperature of $90^{\circ} \mathrm{C}$, and occasionally stirred. The solution was then sieved using flannel cloth while it was still warm, until no sediment was observed ( Rina, et al., 2007)

\section{Phytochemical screening}

Phytochemical screenings including alkaloid tests (Dragendorff, Meyer and Wagner test), flavonoid test (Schinoda test), terpenoids and steroid test (Liebermann Burchard test), tannin tests $\left(\mathrm{FeCl}_{3}\right.$ and gelatin test), Phenolic test $\left(\mathrm{FeCl}_{3}\right)$ and saponins test (bubbling test) were performed on langsat stem bark infusion.

\section{Thin Layer Chromatography (TLC)}

Identification using TLC utilizes $\mathrm{GF}_{254}$ silica plates. Concentrated langsat stem bark infusion was applied onto the TLC plate using capillary tube. The plate developed in a pre-saturated chamber with mobile phase was then developed until designated borderline. Mobile phase used in this research was optimized by varying the mixture of $n$ butanol: acetic acid: water (BAW) with ration of 4:1:5. The plate was then dried in open air, and spots were observed under UV $254 \mathrm{~nm}$ and UV $366 \mathrm{~nm}$ light. $\mathrm{AlCl}_{3}$ was then sprayed onto the plate to visualize spots on the plate (Rivai 2012).

\section{Antioxidant activity preliminary test}

The infusion was applied onto $\mathrm{GF}_{254}$ plate using capillary tube. Mobile phase consisted of BAW mixtures in a ratio of $4: 1: 5$. The plate was developed inside a chamber until it was saturated. The plates were sprayed with $20 \mathrm{ppm}$ of DPPH in methanol. The plate was left for several minutes, and the remain spot were observed. Free radical binder substance could be seen as pale yellow spot with purple background after spraying.

\section{Preparation of Infusion}

This method was chosen based on the empirical uses by Dayaknese ethnic society in Sekajang hamlet by stewing langsat stem bark with boiled water. Dried langsat stem bark powder was stewed with aquadest in a pot using heating plate for 15 minutes, which was then measured after the temperature of the pot reaches $90^{\circ} \mathrm{C}$, while it was stirred occasionally. The solution was sieved through flannel clothes, until no residue was observed.

\section{Antioxidant activity test using UV-Vis \\ Spectrophotometry}

25 grams of langsat stem bark infusion in $250 \mathrm{ml}$ of aquadest with $10 \%$ concentration as stock solutions were made into series of concentration: 1000 ppm; 2000 ppm; $3000 \mathrm{ppm} ; 4000$ ppm; and $5000 \mathrm{ppm}$. Each solutions was pipetted for $1 \mathrm{ml}$ into several test tube. In every tube, $3 \mathrm{ml}$ of $20 \mathrm{ppm}$ DPPH were added, and aquadest was added up to $5 \mathrm{ml}$, and the test tubes were incubated at $37^{\circ} \mathrm{C}$ for 30 minutes. Blanks used were $95 \%$ methanol. Absorbance was measured at $515.5 \mathrm{~nm}$ wave length. $\mathrm{IC}_{50}$ was calculated separately using regression equation.

\section{Analgesic activity assessment of langsat stem bark infusion}

Several mice used in this test were fasted for $\pm 12 \mathrm{~h}$, by continuous supply of water, when oral was used as the route of test substance. Mice were weighed, and randomly grouped into several groups consisting of 5 mice in each group, such as negative control group by giving $\mathrm{CMC} \mathrm{Na}$ $0,5 \%$; positive control group by giving comparison drug (paracetamol suspension); Dose group 1 administered by langsat stem bark infusion of $65 \mathrm{mg} / \mathrm{kg} \mathrm{BW}$; Dose group 2 by giving langsat stem bark infusion of $130 \mathrm{mg} / \mathrm{kg} \mathrm{BW}$; and Dose group 3 given by langsat stem bark infusion of $195 \mathrm{mg} / \mathrm{kg}$ BW. Thirty minutes after the administration of test substances, $0.6 \%$ acetic acid was injected via intraperitoneal. Writhing of the mice was observed every 5 minutes for 60 minutes. Observation was conducted after the induction of pain substance. Writhing data of mice every 5 minutes for 60 minutes was tabulated for each mouse. Analgesic assessment data was analyzed using One Way ANOVA. This research has been approved by ethics committee from Faculty of Medicine, University of Tanjungpura, Pontianak, indonesia ethics commission no 6078/UN22.9/DT/2016.

\section{RESULTS AND DISCUSSION}

\section{Phytochemical screening}

Phytochemical screening is the first step to identify the chemical content contained in plants, because in this stage we can know the chemical compound group contained in the plant we are testing. The phytochemical screening using test tube method showed that langsat stem bark infusion contained flavonoid, terpenoids and steroids, phenolic, tannin and saponins (Table 1). Alkaloids apparently have nonpolar properties, so that the use of aquadest as polar properties in the infusion preparation of langsat stem bark, resulted in alkaloid could not successfully being extracted from the stem bark.

In order to more identify the metabolite compounds of langsat stem bark infusion, the analysis using thin layer chromatography has been also conducted. Results showed that compound separation in the form of chromatogram pattern showed the spot separation after it has been visualized with or without visualization reagent (spray) in visible light, or ultraviolet light in $254 \mathrm{~nm}$ and $366 \mathrm{~nm}$ wavelength (Ministry of Health of the Republic of Indonesia 1995). These separated compounds were used in 
the form of solution, in order to produce a spot or band. According to Harbone, for flavonoid compounds, BAW mobile phase could be used for visualization of the compounds in TLC (Harborne 1973). Result shows that the sample contains flavonoid, can we see at Figure 1.

\section{Antioxidant activity tests}

Mobile phase which is used for antioxidant test using TLC is a mixture of n-butanol: acetic acid: water with a ratio of $4: 1: 5$. The use of this mobile phase is based on optimization using several solvents and ratio. The best separation of compounds was achieved using BAW (4:1:5) mobile phase. From figure 2 the separation of concentrated infusion using BAW resulted in 3 separated spots. Visually, it could be seen that two of the spot was brown, and one of the spots was green. Detection using UV $366 \mathrm{~nm}$ light was also conducted to visualize fluorescence spot. The obtained spots might be due to the interaction between UV light and the chromophore paired with auxochrome (Pratiwi et al. 2013). TLC plates were then sprayed with 1000 ppm DPPH solvent. Qualitative antioxidant activity test shows brownish yellow color with purple background. This result was also supported by the results of phytochemical screening, where langsat stem bark infusion contains flavonoid.

The langsat stem bark powder was made into infusion with a concentration of $10 \%$ as stock solution. In order to confirm the antioxidant activity, the analysis using UV-Vis Spectrophotometry has been also conducted. Based on visual observation, it can be seen that langsat stem bark infusion sample which has been reacted with DPPH and incubated for 30 minutes had changed color from purple to

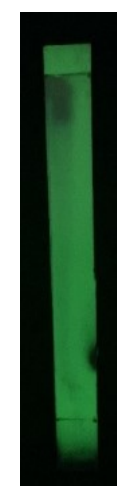

A

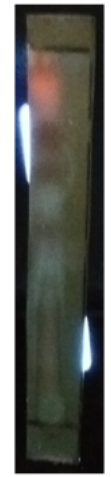

B

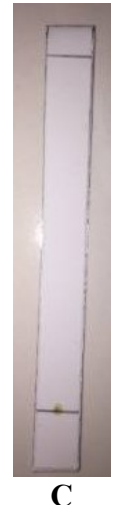

C
Figure 1. Results of Flavonoid Chromatogram Pattern using TLC. A. Spots observed under UV $254 \mathrm{~nm}$; B. Spots observed under UV $366 \mathrm{~nm}$; C. Spots observed after being sprayed with $\mathrm{AlCl}_{3} 5 \%$ in methanol reagent

washed out purple (Figure 2). The formation of golden yellow color is caused by the picril group in DPPH solution (Molyneux 2004).

The result of antioxidant activity is interpreted as $\mathrm{IC}_{50}$. $\mathrm{IC}_{50}(50 \%$ inhibition concentration $)$ is a minimum concentration of a solution that can inhibit free radical activity up to $50 \%$. The lower $\mathrm{IC}_{50}$ is, the higher antioxidant activity of the test substances (Molyneux 2004).

The calculation of inhibitory regression is $\mathrm{y}=0.002 \mathrm{x}+$ 44.36 (figure 3 ) and percentage resulted in $\mathrm{IC}_{50}$ of langsat stem bark infusion at $2820 \mathrm{ppm}$, table of percentage inhibition stem bark infusion can we see at Table 2. Based on Molyneux (2004) classification, where langsat stem bark ethanolic extract has an $\mathrm{IC}_{50}$ of $174.19 \mathrm{ppm}$, and raw langsat stem bark ethanolic extract has an $\mathrm{IC}_{50}$ of 205.38 $\mathrm{ppm}$. The difference in $\mathrm{IC}_{50}$ can be as a result of different solvent used, and methods of extraction. The temperature and period of stewing in infusion preparation could result in differences in antioxidant activity (Wassalwa 2016).

Table 1. Phytochemical screening results of langsat stem bark infusion

\begin{tabular}{lc}
\hline Tests & Results \\
\hline Alkaloid & $(-)$ \\
Flavonoid & $(+)$ \\
Terpenoids and steroid & $(+)$ \\
Tannin & $(+)$ \\
Phenol & $(+)$ \\
Saponins & $(+)$ \\
\hline
\end{tabular}

Note: (+) Detected; (-) Not Detected

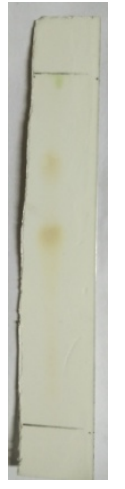

A

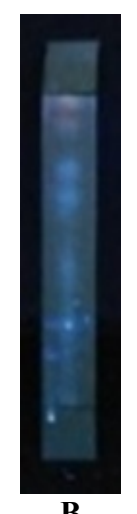

B

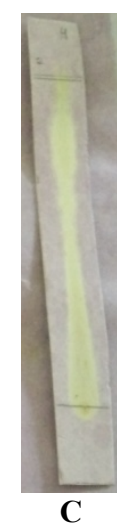

Figure 2. Antioxidant Activity Test using TLC. A. Visual appearances; B. Visualization under UV $366 \mathrm{~nm}$ light; C. Visualization after being sprayed with 20 ppmDPPH 20 reagent

Table 2. Inhibition concentration of langsat stem bark infusion resulted from UV spectrophotometer wavelength $(\lambda) 515,1$

\begin{tabular}{lcccc}
\hline $\begin{array}{l}\text { Concentration } \\
(\mathbf{p p m})\end{array}$ & Absorbance & \% Averange inhibition & Linier regression & IC $_{\mathbf{5 0}}$ \\
\hline 1000 & $0.26339 \pm 0.0074$ & 46.82857 & $\mathrm{y}=0.002 \mathrm{x}+44.36$ & \\
2000 & $0.24978 \pm 0.0006$ & 49.57607 & \\
3000 & $0.23710 \pm 0.0081$ & 52.13582 & \\
4000 & $0.22403 \pm 0.0151$ & 54.77431 & \\
\hline
\end{tabular}




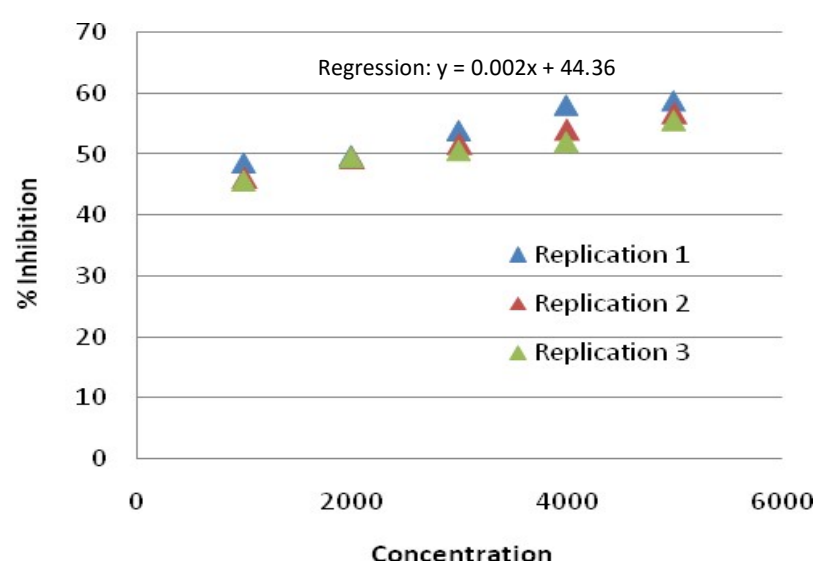

Figure 3. Percentage inhibition langsat stem bark infusion

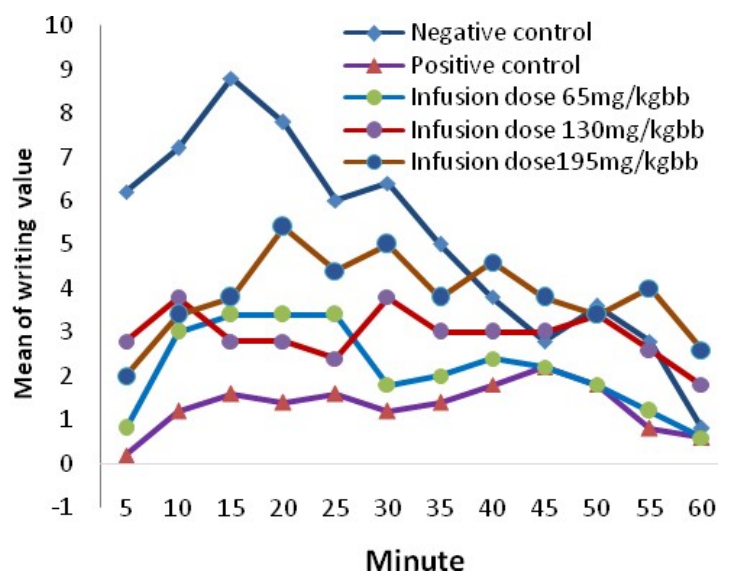

Figure 4. Mean writhing value of mice writhing after induction every 5 minutes over 60 minutes

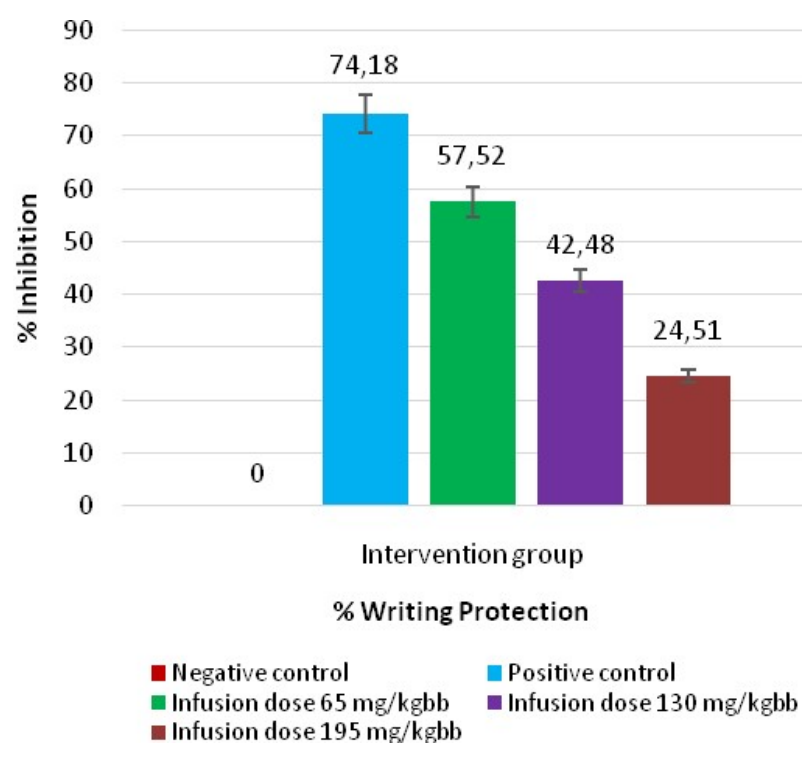

Figure 5. Test substance writhing protection percentage
The compounds suspected of antioxidant activity in plants are phenolic and flavonoids groups. Phenol compounds are antioxidants activity because the compound caracter has reducing caracter of hydrogen donors. The antioxidant activity of phenol compounds is determined by the molecular structure, number and position of the hydroxyl groups in the aromatic rings and unpaired electrons in the phenol compound involved in the delocalization of electrons (Lugasi et al. 2003). Flavonoids have antioxidant effects through two mechanisms. The first mechanism is to inhibit the enzymes responsible for the production of superoxide anions, hydroxyl radicals and SORs, such as xanthine oxidase, protein kinase C, cyclooxygenase, lipooxygenase, microsomal monooxygenase, glutathione s-transferase, mitochondrial succinooxidase and NADH oxidase. The second mechanism is flavonoid can reduce free radicals such as superoxide radicals, peroxyl, alkoxyl and hydroxyl by giving hydrogen atoms to a stable quinone structure (Amic et al. 2003).

\section{Analgesic activity assessment of langsat stem bark infusion}

Analgesic test in this research used 3 variance dose i.e lower dose $65 \mathrm{mg} / \mathrm{kg} \mathrm{BW}$, dose $130 \mathrm{mg} / \mathrm{kg} \mathrm{BW}$, and higher dose $195 \mathrm{mg} / \mathrm{kg} \mathrm{BW}$. Writhing value in samples treated with variance dose was low than negative control $\mathrm{Na} \mathrm{CMC} 0,5 \%$. Writhing value of sample treated with stem bark infusion at the dose of $65 \mathrm{mg} / \mathrm{kg} \mathrm{BW}$ had maximal effect compared to those samples treated at the dose of 130 $\mathrm{mg} / \mathrm{kg} \mathrm{BW}$ and dose of $195 \mathrm{mg} / \mathrm{kg} \mathrm{BW}$. The dose of 65 $\mathrm{mg} / \mathrm{kg} \mathrm{BW}$ of stem bark infusion showed ineffective performance than that from positive control paracetamol.

Based on the protection percentage graph, it can be seen that the best protection percentage of test substance in reducing mice writhing was achieved from positive control group, followed by dose 1,2 and 3 of langsat stem bark infusion and negative control group. The availability of other secondary metabolites could be synergist or antagonist towards desired effect. Antagonist effect could be potentially disadvantageous due to lowered analgesic effectiveness (Molyneux 2004). Based on the graph, it can be concluded that langsat stem bark infusion had an analgesic effect in dose of $65 \mathrm{mg} / \mathrm{kg} \mathrm{BW}, 130 \mathrm{mg} / \mathrm{kg} \mathrm{BW}$ and $195 \mathrm{mg} / \mathrm{kg} \mathrm{BW}$ with writhing protection percentage of $57.52 \% ; 42.48 \%$; and $24.51 \%$ respectively. Effective dose of langsat stem bark infusion potential used as analgesic properties was at a dose of $65 \mathrm{mg} / \mathrm{kg} \mathrm{BW}$.

Based on data analysis using One Way ANOVA, results showed that inhibition percentage between dose 1 group with the langsat stem bark infusion at dose of $65 \mathrm{mg} / \mathrm{kg}$ $\mathrm{BW}$ had significant differences compared to that in positive control group (paracetamol, $65 \mathrm{mg} / \mathrm{kg} \mathrm{BW}$ ). This means that dose 1 of langsat stem bark infusion had the lower analgesic effects compared to paracetamol in terms of reducing pain.

In conclusion, based on antioxidant and analgesic assessment of langsat stem bark infusion, it can be concluded that langsat stem bark infusion had a weak 
antioxidant properties with $\mathrm{IC}_{50}$ of $2820 \mathrm{ppm}$. Langsat stem bark infusion had analgesic properties with a dose of 65 $\mathrm{mg} / \mathrm{kg} \mathrm{BW}, 130 \mathrm{mg} / \mathrm{kg} \mathrm{BW}$, and $195 \mathrm{mg} / \mathrm{kg} \mathrm{BW}$, with writhing protection at percentage of $57.52 \%, 42.48 \%$, and $24.51 \%$ respectively. Effective dose of langsat stem bark infusion as an analgesic was obtained at the dose of 65 $\mathrm{mg} / \mathrm{kg} \mathrm{BW}$.

\section{ACKNOWLEDGEMENTS}

This research was supported by Ministry of Health of the Republic of Indonesia through BBP2TOOT grant riset RISTOJA 2016.

\section{REFERENCES}

Amic D, Beslo D, Trinajstic N. 2003. Structure-radical scavenging activity relationships of flavonoids. Croat Chem Acta76(1): 55-61.

Ebadi M. 2001. Pharmacodynamic Basis of Herbal Medicine. CRC Press, Washington DC.

Harborne JB. 1973. Phytochemical Methods: A Guide to Modern Techniques of Plant Analysis. Chapman \& Hall, London.

Koesyanto H. 2013. Working period and work attitude sit against back pain. KeMas 9 (1): 9-14. [Indonesian]

Kurniawan A. 2011. Antioxidant activity and biological potential of the combination of four types of medicinal plants of Indonesia. [Hon. Thesis]. Department of Biochemistry, Bogor Agricultural University, Bogor .

Lugasi A, Hovari J, Sagi KV, Biro L. 2003. The role of antioxidant phytonutrients in the prevention of diseases. Acta Biologica Szegediensis 47(1): 119-125.

Ministry of Health of the Republic of Indonesia. 1995. Materia Medika. Issue VI. Ministry of Health Republic of Indonesia, Jakarta. [Indonesian]
Ministry of Health of the Republic of Indonesia. 2015. InfoDATIN: Data and information center. Ministry of Health Republic of Indonesia, Jakarta. [Indonesian]

Molyneux P. 2004. The use of stable free radical diphenylpicrylhiydrazyl (DPPH) for estimating antioxidant activity. J Sci Technol 26 (2): 212 218.

Mokosuli YS. 2008. Antioxidant and anticancer activity of leaf bark extract (Lansium domesticum L.). [Thesis]. Graduate School of IPB. Bogor. Indonesia.

Muchtadi D. 2013. Antioxidants and Healthy Tips in the Productive Age. Alfabeta, Bandung. [Indonesian]

Pratiwi D, Wahdaningsih S, Isnindar. 2013. Test activity of lower leaves of mecca (Eleutherine americana Merr.) With DPPH method (2,2diphenyl-1-picrilhidrazil). Trad Med J 18 (1): 9-16.

Rivai H. 2012. Study method of analysis of Natural Materials Containing Phenolic Compounds for the Development of Monograph Data of Indonesian medicinal plants. [Thesis]. University of Andalas, Padang. [Indonesian]

Rina A, Nurcahyati W, Arifah SW. Salam (Eugenia polyantha Wight) Leaf Infusa Effect In Reducing Male Mice Uric Acid Level Induced By Potassium Oxonate. Pharmacon Vol 8(2): 56-63.

Sadeli S, Maulidi, Afandi, Melsilawati W, Rizkifani S. 2015. Special Research on Local Ethnomedicin and Community-Based Drugs Exploration Research in Indonesia. Indonesian Center for Research and Development of Medicinal and Traditional Medicinal Plants, Karanganyar. [Indonesian]

Semuel MY. 2008. Activity of Antioxidant and Anticancer of Leaf Bark Extract (Lansium domesticum L.). [Thesis]. Bogor Agricultural University, Bogor.

Subandrate, Sinulingga S, Wahyuni S, Altiyan MF, Fatmawati. 2016. The antioxidant potency of duku seed extract (Lansium domesticum Corr.) in white rats (Rattus novergicus) induced by alcohol. Molecule 11(1): $1-8$.

Tjay TH, Rahardja K. 2007. Important Medicines: Efficacy of use and its side effects. Issue VI. Ministry of Health of the Republic of Indonesia, Jakarta. [Indonesian]

Wassalwa M. 2016. Influence of infusa time and different water temperature on antioxidant activity and vitamin $\mathrm{C}$ on infused water banana skin. Jurnal Ilmiah Mahasiswa Pendidikan Biologi (JIMPBio) 1 (1): 107-118. [Indonesian] 